University of Rhode Island

DigitalCommons@URI

The Rhode Island Current Conditions Index

Economics

$11-2018$

\title{
Rhode Island Current Conditions Index - November 2018
}

Leonard Lardaro

University of Rhode Island, lardaro@uri.edu

Follow this and additional works at: https://digitalcommons.uri.edu/ricci

Part of the Econometrics Commons

Terms of Use

All rights reserved under copyright.

\section{Recommended Citation}

Lardaro, Leonard, "Rhode Island Current Conditions Index -- November 2018" (2018). The Rhode Island Current Conditions Index. Paper 179.

https://digitalcommons.uri.edu/ricci/179

This Newsletter is brought to you for free and open access by the Economics at DigitalCommons@URI. It has been accepted for inclusion in The Rhode Island Current Conditions Index by an authorized administrator of DigitalCommons@URI.For more information, please contact digitalcommons-group@uri.edu. 


\title{
CURRENT CONDITIONS
}

\section{LEONARD LARDARO, URI}

\author{
Available Online: http: / /www.Ilardaro.com/current.htm \\ Twitter: @ladardo
}

VOL XXV

NUMBER 12

NOV 2018

While the performance of Rhode Island's economy in the fourth quarter of 2018 began in a manner that I described last month as awful, we appear to have gotten somewhat of a reprieve in November. Individual indicator performances last month were among the worst in a very long time. Not so, this month. The November Current Conditions Index rose from its contraction value of 42 last month to 58 in November, returning to the expansion range. However, the CCI has remained noticeably weaker since its most recent high of 92 in May. Evidence of this is not very difficult to find, as it is evident in an increasing number of economic indicators. Payroll employment, the number of jobs in Rhode Island, experienced its recent peak in July. Our state's Labor Force reached its peak in August, so recent monthly improvements in our state's Unemployment Rate have occurred for the wrong reasons. A worry: Is our Labor Force on the verge of resuming its VERY long-term secular decline (i.e., train wreck trend)? The employment rate, the percentage of our working-age population that is employed has been stuck at 62.3 percent since August, remaining well below its prior high of 65.4 percent from al the way back to 2007! The labor force participation rate, the percentage of the working-age population in the Labor Force, has declined for the most recent three months. While both have fared better in 2018 than prior years and remain well below their 2007 highs, their earlier-gains appear to be eroding.

\begin{tabular}{|l|r|r|}
\hline \multicolumn{3}{|c|}{ CCI Indicators - \% Change } \\
\hline Government Employment & -0.3 & \\
\hline US Consumer Sentiment & -6.4 & \\
\hline Single-Unit Permits & -2.3 & \\
\hline Retail Sales & $\mathbf{8 . 3}$ & $\mathrm{Y}$ \\
\hline Employment Services Jobs & 2.6 & $\mathrm{Y}$ \\
\hline Priv. Serv-Prod Employment & 1.5 & $\mathrm{Y}$ \\
\hline Total Manufacturing Hours & $-\mathbf{0 . 1}$ & \\
\hline Manufacturing Wage & -3.8 & \\
\hline Labor Force & $\mathbf{0 . 9}$ & $\mathrm{Y}$ \\
\hline Benefit Exhaustions & $-\mathbf{1 9 . 2}$ & $\mathrm{Y}$ \\
\hline New Claims & -2.2 & $\mathrm{Y}$ \\
\hline Unemployment Rate (change) & -0.7 & $\mathrm{Y}$ \\
\hline \multicolumn{2}{|c|}{ Y = Improved Value } \\
\hline
\end{tabular}

In spite of all of this, for now at least, any debate concerning whether Rhode Island has slipped into a recession can be dismissed. Since we are FILO, however, continually monitoring our state's economic condition is a necessity.

Not surprisingly, the CCI failed to exceed its year-earlier value yet again this month, the ninth time in 2018. The good news, believe it or not, is that two of the five leading indicators contained in the CCI managed to improve in November, a distinct improvement from 0 last month. So, Rhode Island continues to experience the end of its 2017 "sugar high." Each month, we face comps that are increasingly difficult to beat.

At least we can say that since the recent May high, the CCI has not gone straight down, and we did manage to pull ourselves up from a very weak October value. A distinct possibility is that since historically, labor market values for October through December are very often altered through rebenchmarking, recent weakness is largely a statistical illusion. Trust me when I say this would not be the first time this happened.

For November, seven of the CCI indicators improved. Individual indicator performances were far less weak than those in October. New Claims, the timeliest measure of layoffs, fell, albeit barely $(-2.2 \%)$, its third decrease in the last six months. Hopefully layoffs might not trend higher after all. Rhode Island's goodsproducing sector's performance was very bad again in November. Total Manufacturing Hours, a proxy for manufacturing output, an important part of Rhode Island's recent strength, fell for a second consecutive month $(-0.1 \%)$. The workweek lengthened but employment fell. The Manufacturing Wage declined again in November $(-3.8 \%)$. Single-Unit Permits, which reflect new home construction, continued their recent string of declines $(-2.3 \%)$, based on my estimate since its value was unavailable due to the government shutdown. Employment Service Jobs, a leading labor market indicator that includes temporary employment, improved $(+2.6 \%)$ after failing to do so last month US Consumer Sentiment fell in November $(-6.4 \%)$, calling its recent uptrend into question.

As noted earlier, both of the "left behind" indicators, the employment rate and the labor force participation rate, failed to improve again in November, raising questions about the sustainability of their uptrends that began in January. Sadly, both have remained well below their prior cyclical highs (see table), so they might never exceed those values during this entire cycle.

Retail Sales grew strongly again $(+8.3 \%)$, Government Employment fell from its level a year ago for a third consecutive month $(-0.3 \%)$, Private Service-Producing Employment growth remained below rates mid-year while still remaining above one percent $(+1.5 \%)$, and Benefit Exhaustions, the timeliest measure of longer-term unemployment, continued its downtrend in November $(-19.2 \%)$. The Unemployment Rate remained below 4 percent, driven largely by a Labor Force that fell for the third consecutive time on a monthly basis.

$\begin{array}{rrr}\text { LABOR FORCE; } & \text { Nov 2018 } & \text { Peak (1/2007) } \\ \text { Participation Rate } & 64.7 \% & 68.6 \% \\ \text { Employment Rate } & 62.3 \% & 65.4 \%\end{array}$

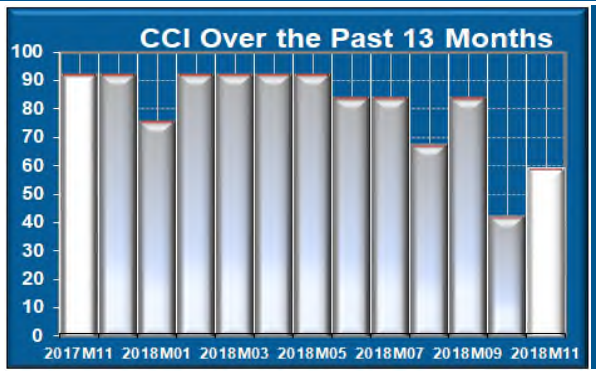

\section{DLT Nov 2018 Employment} $(\mathbf{S A}, \mathbf{Y} / \mathbf{Y})$

Gain

5,900

Loss

800

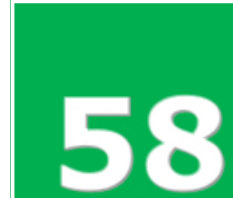

\begin{tabular}{|l|l|l|l|l|}
\hline & Jan & Feb & Mar & Apr \\
\hline 2017 & $75 \uparrow$ & $83 \uparrow$ & $92 \uparrow$ & $75 \uparrow$ \\
\hline 2018 & 75 & 92 & 75 & $75 \uparrow$ \\
\hline
\end{tabular}

\begin{tabular}{|l|l|l|l|l|l|l|l|}
\hline May & Jun & Jul & Aug & Sep & Oct & Nov & Dec \\
\hline $83 \uparrow$ & $92 \uparrow$ & $75 \uparrow$ & $92 \uparrow$ & $92 \uparrow$ & $92 \uparrow$ & $92 \uparrow$ & $83 \uparrow$ \\
\hline 92 & 83 & 75 & $83 \uparrow$ & 67 & 42 & 58 & \\
\hline
\end{tabular}

\section{Net Chg $\quad 5,100$ \\ Net Chg $\quad 5,100$}

Copyright $\odot$ 2017, 2018 Leonard Lardaro, Ph.D. All rights reserved. 